\title{
Pharmacogenomics Study of Clopidogrel by RFLP based Genotyping of CYP2C19 in Cardiovascular Disease Patients in North-East Population of India
}

\section{Prasanthi SV', Vinayak S Jamdade ${ }^{2}$, Nityanand B Bolshette', Ranadeep Gogoi ${ }^{1 *}$ and MangalaLahkar ${ }^{2,3}$}

${ }^{1}$ Department of Biotechnology, National Institute of Pharmaceutical Education and Research (NIPER), Gauhati Medical College, Guwahati, Assam, India ${ }^{2}$ Department of Pharmacology and Toxicology, National Institute of Pharmaceutical Education and Research (NIPER), Gauhati Medical College, Guwahati, Assam, India ${ }^{3}$ Department of Pharmacology, Gauhati Medical College, Guwahati, Assam, India

\begin{abstract}
Introduction and Objective: Pharmacogenetics is a genetically determined variability in drug responses. The genes and their allelic variants which affect our response to drugs are the main routes in development of pharmacogenetics. Clopidogrel is an antiplatelet drug, used against athero-thrombotic events in cardiovascular patients. The objective of our study was to identify the CYP2C19 Single Nucleotide Polymorphisms, responsible for altering the metabolism of clopidogrel, at gene level. And to document the prevalence of CYP2C19 gene mutations in clopidogrel treated cardiovascular disease patients in Assam population, Guwahati Medical College \& Hospital, in North- East India.

Patients and Methods: We have studied 60 patients who received clopidogrel from Gauhati medical college and hospital Assam. Genomic DNA was extracted by using Hipura blood genomic DNA extracting mini preparation kit by following the manufacturer's instructions. RFLP analysis was done by DNA amplification which was carried out by using set of primers and resulting ampicons of CYP2C19*2;CYP2C19*3 and CYP2C19*17 were subjected for Restriction digestion with Smal, BamHI and $L w e O /$ respectively.

Results: We found that CYP2C19*2 had allelic frequency of $\sim 40 \%$ in Gauhati Medical College and Hospital, Assam, North East India. None of the samples were mutated with CYP2C19*3 andCYP2C19*17 allele. Other CYP2C19 variant alleles with reduced or absent enzymatic activity have been identified.

Conclusion: We found that loss of functional allele CYP2C19*2 had higher carriage frequency; whereas, CYP2C19*3 and * 17 alleles were not found in cardiovascular patients who were taking clopidogrel. Personalized therapy targeting patients who carry these genetic variants might help to improve the clinical outcome.
\end{abstract}

Keywords: Clopidogrel; Pharmacogenomics; CYP2C19; RFLP analysis

\section{Introduction}

Variation of individual persons in response to drug is crucial clinical problem. Optimal drugs and doses regimen depends on various factors such as gender, age, body weight, organ function, comorbidity, drug-drug interactions, disease states, culture, lifestyle, race race/ethnicity, genetics, smoking, diet [1]. However, genetic variation can make up as much as $95 \%$ of variability in drug disposition and its effect [2-6]. Clopidogrel is an antiplatelet drug, used against atherothrombotic events in patients undergoing percutaneous coronary interventions (PCIs) with stent implantation [7-11]. Clopidogrel after biotransformation by Cytochrome 2C19 inhibits platelet activation through an irreversible blockage of adenosine diphosphate (ADP) P2Y12 receptor [12-22]. CYP2C19 gene, member of CYP450 family is highly polymorphic, as it is occurring in 25 variant alleles. The aims of this study were to determine the prevalence of clinically relevant CYP2C19², CYP2C19*3 and CYP2C19*17 genes in North East India, study population and finally determine whether the allele distributes and predicts metabolic phenotype in clopedogrel treatment patients. Study population include $90 \%$ male with an average of about 50.66 years. All other statistical analysis were carried out with the level of significance set at $P<0.05$. The most common CYP2C19 loss-offunction allele is ${ }^{\star} 2$ (c.681G $>A$; rs4244285), with allele frequencies of $\sim 15 \%$ in Caucasians and Africans, and $29-35 \%$ in Asians [22-26]. Other CYP2C19 variant alleles with less or no enzymatic activity have been recognised (e.g., ${ }^{\star} 3-{ }^{\star} 8$ ); nevertheless, their allele frequencies are typically $<1 \%$, with the exception of CYP2C19*3 (c.636G $>A$; rs4986893) in Asians (2-9\%) [24,27-32]. Based on identified CYP2C19 genotypes, individuals can be categorized as extensive metabolizers (e.g., ${ }^{\star} 1 /{ }^{\star} 1$ ), intermediate metabolizers (e.g., ${ }^{\star} 1 /{ }^{\star} 2$ ), or poor metabolizers (e.g., ${ }^{*} 2 /{ }^{*}$ ) (Table 1). The frequencies of CYP2C19 poor metabolizers are $\sim 2-5 \%$ among Caucasians and Africans and $\sim 15 \%$ in Asians. In contrast, the CYP2C19*17 allele (c.-806C $>\mathrm{T}$; rs12248560) results in increased activity, with normal multi-ethnic allele frequencies of $\sim 3$ $21 \%$ [33-35]. Individuals who possess this allele may be categorized as ultra-rapid metabolizers (e.g., ${ }^{\star} 17 /{ }^{*} 17$ ). Some studies reveals that this allele results in enhanced platelet inhibition and clopidogrel response $[30,33,34]$, and perhaps an increased risk of bleeding complications [28]. However, other studies have not documented an effect of $C Y P 2 C 19^{*} 17$, and satisfactory evidence for an independent effect of this allele on clinical outcomes is missing $[31,35,36]$. In this study,

*Corresponding author: Ranadeep Gogoi, Laboratory of Biotechnology, Department of Biotechnology, National Institute of Pharmaceutical Education and Research (NIPER), Gauhati Medical College, Guwahati-781032, Assam, India, Tel: +918486335304; E-mail: gogoiranadeep@yahoo.co.in

Received March 22, 2014; Accepted May 07, 2014; Published May 14, 2014

Citation: Prasanthi SV, Jamdade VS, Bolshette NB, Gogoi R, Lahkar M (2014) Pharmacogenomics Study of Clopidogrel by RFLP based Genotyping of CYP2C19 in Cardiovascular Disease Patients in North-East Population of India. J Pharmacogenomics Pharmacoproteomics 5: 132. doi:10.4172/2153-0645.1000132

Copyright: (c) 2014 Prasanthi SV, et al. This is an open-access article distributed under the terms of the Creative Commons Attribution License, which permits unrestricted use, distribution, and reproduction in any medium, provided the original author and source are credited. 
Citation: Prasanthi SV, Jamdade VS, Bolshette NB, Gogoi R, Lahkar M (2014) Pharmacogenomics Study of Clopidogrel by RFLP based Genotyping of CYP2C19 in Cardiovascular Disease Patients in North-East Population of India. J Pharmacogenomics Pharmacoproteomics 5: 132. doi:10.4172/2153-0645.1000132

Page 2 of 5

we shows that the frequency of allelic variation of $C Y P 2 C 19^{\star} 2$ allele is $\sim 40 \%$ in comparison with allele frequencies of $\sim 15 \%$ in Caucasians and Africans, and $29-35 \%$ in Asians.

\section{Materials and Methods}

\section{Sample size}

We have studied 60 patients who received clopidogrel from Gauhati medical college and hospital Assam, for period of six month from September 2012 to February 2013. $2 \mathrm{ml}$ of whole blood for DNA extraction was collected using 20-gauge needle and syringe in EDTA tubes which were obtained after informed consent according to declaration of Gauhati medical college and Hospital, Guwahati.

\section{DNA extraction}

Genomic DNA was extracted by using Hipura blood genomic DNA extracting mini preparation kit by following the manufacturer's instructions. The presence of DNA was confirmed by running DNA in $0.8 \%$ agarose gel.

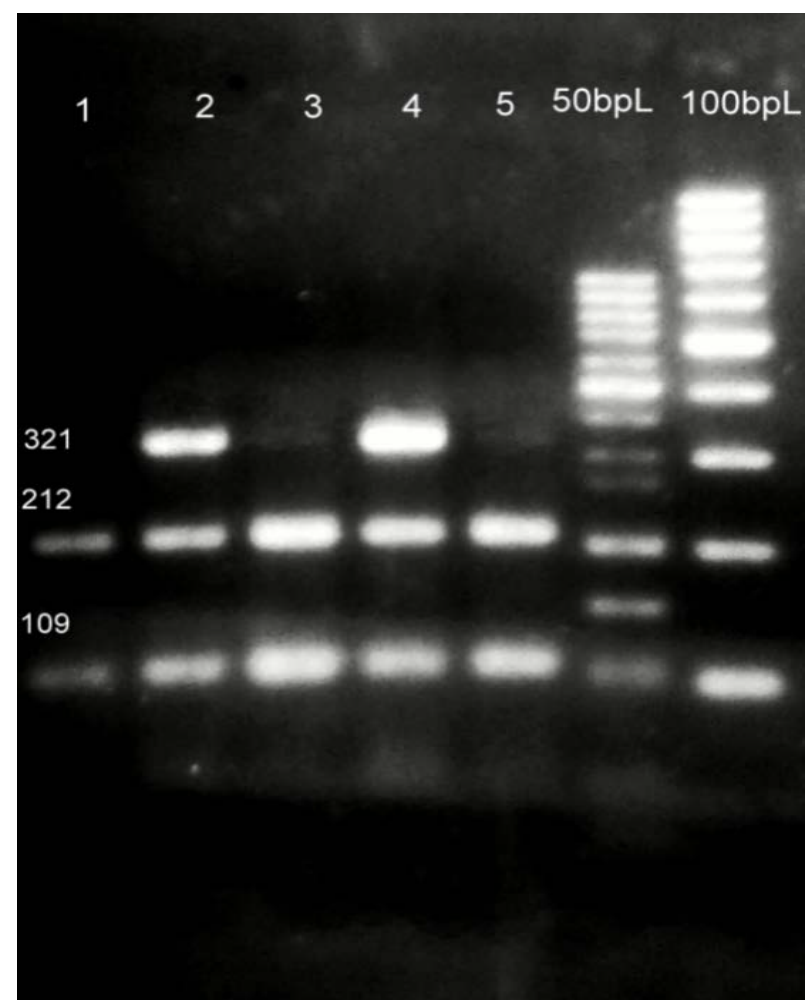

Lane 1, 3, 5: wild type; lane 2, 4: heterozygous variants, lane 6 and 7: $50 \mathrm{bp}$ and $100 \mathrm{bp}$ molecular weight markers respectively.

Figure 1: PCR-RFLP based genotyping of CYP2C19 gene allele *2.

\section{Genotyping procedure PCR}

CYP $2 C 19^{\star} 1{ }^{\star} 2^{\star} 3$ and ${ }^{*} 17$ genotyping: DNA amplification was carried out by using set of primers which were selected from published literature and confirmed by using BLAST analysis. Two PCR reactions specific for $* 2$ and $* 3$ were conducted in parallel for each specimen in a final volume of $20 \mu \mathrm{l}$. CYP2C19*2 amplification was done with 5'-CAGAGCTTGGCATATTGTATC-3'; 5'-GTAAACACACAAAACTAGTCAATG-3'sense and antisense primers respectively at $94^{\circ} \mathrm{C}$ as initial denaturation for $5 \mathrm{~min}$ with 35 cycles of $94^{\circ} \mathrm{C}$ for $20 \mathrm{sec}$ as a denaturation, annealing at $53^{\circ} \mathrm{C}$ for $10 \mathrm{sec}$, with polymerization at $72^{\circ} \mathrm{C}$ for $10 \mathrm{sec}$ and final extension of $72^{\circ} \mathrm{C}$ for $5 \mathrm{~min}$. For amplification of $C Y P 2 C 19^{*} 3$ gene, 5'AACATCAGGATTGTAAGCAC-3' and 5'-TCAGGGCTTGGTCAATATAG-3' primers with same PCR conditions as above for $C Y P 2 C 19^{\star} 2$ were used. However, $C Y P 2 C 19^{*} 17$ were carried out by set of 5'-GCCCTTAGCACCAAATCTTC-3'; 5'TTTAACCCCCTAAAAAAACACG-3' primers. CYP2C19¹7 allele PCR conditions were used as, $94^{\circ} \mathrm{C}$ initial denaturation for ten minutes ; 35 cycles of $94^{\circ} \mathrm{C}$ for 30 seconds (denaturation), $58^{\circ} \mathrm{C}$ for 30 seconds (annealing); $72^{\circ} \mathrm{C}$ for 45 seconds (extension); and final extension of $72^{\circ} \mathrm{C}$ for 10 minutes.

\section{RFLP analysis}

Resulting amplicons of CYP2C19*2; CYP2C19*3 and CYP2C19* 17 were subjected for restriction digestion with SmaI, BamHI and LweI (New England Biolabs) respectively. CYP2C19²; CYP2C19³ PCR products were digested at $37^{\circ} \mathrm{C}$ for 1 hour and digestion of CYP2C19*17 amplicon was carried out with LweI for 3 hour at same temperature. Enzyme deactivation was done at $65^{\circ} \mathrm{C}$ for $20 \mathrm{~min}$ and the resulted RFLP products were analysed by $2.5 \%(\mathrm{w} / \mathrm{v})$ agarose gel electrophoresis.

\section{Result}

Genomic DNA of sufficient quality and quantity was extracted from 50 blood samples from Gauhati Medical College and Hospital, in Assam. Amplification of the $C Y P 2 C 19^{*} 2$, CYP2C19*3 and $C Y P 2 C 19^{*} 17$ target sequence from these archival samples resulted in 321, 119 and $438 \mathrm{bp}$ products, respectively. Digestion of the CYP2C19² amplicon with SmaI resulted in products of 212 and $109 \mathrm{bp}$ (homozygous wild type; c.681 G/G); 321, 212 and $109 \mathrm{bp}$ (heterozygote; G/A); and a single undigested product of $321 \mathrm{bp}$ (homozygous ${ }^{\star} 2$; A/A) (Figure 1). Digestion of the CYP2C19*3 amplicon with BamHI resulted in products of 93 and $26 \mathrm{bp}$ (homozygous wild-type; codon $636 \mathrm{G} / \mathrm{G}$ ); products of 119,93 and 26 bp (heterozygote ${ }^{\star} 3$; G/A); and a single undigested product of 119 bp (homozygous 3 ; A/A) (Figure 2). Digestion of CYP2C19*17 (wild type; $-806 \mathrm{C}$ ) amplicon with LweI resulted in products of 183 , 142, 113 bp (Tables 2 and 3).

Allelic frequencies were calculated for CYP2C19 gene with $* 2$, ${ }^{\star} 3$ and ${ }^{\star} 17$ alleles by using the Hardy-Weinberg equation $\left(p^{2}+2 p q\right.$ $\left.+q^{2}=1\right)$. Where $q$ is the number of the variant alleles $\left(C Y P 2 C 19^{*} 2\right.$,

\begin{tabular}{|c|c|}
\hline Likely Phenotype & $\begin{array}{c}\text { Examples of } \\
\text { Diplotypes }\end{array}$ \\
\hline Ultrarapid metabolizer: normal or increased activity $(\sim 5-30 \%$ of patients) & $\begin{array}{c}\text { An individual carrying two increased-activity alleles }\left({ }^{*} 17\right) \text {, or one } \\
\text { functional allele }\left({ }^{*} 1\right) \text { plus one increased-activity allele }\left({ }^{*} 17\right)\end{array}$ \\
\hline Extensive metabolizer: homozygous wild-type or normal activity $(\sim 35-50 \%$ of patients) & An individual carrying two functional $\left({ }^{*} 1\right)$ alleles \\
\hline Intermediate metabolizer: heterozygote or intermediate activity $(\sim 18-45 \%$ of patients $)$ & $\begin{array}{c}\text { An individual carrying one functional allele }\left({ }^{*} 1\right) \text { plus one loss-of- } \\
\text { function allele }\left({ }^{*} 2-{ }^{*} 8\right)\end{array}$ \\
\hline
\end{tabular}

Table 1: Assigning likely CYP2C19 phenotypes based on genotypes. 
Citation: Prasanthi SV, Jamdade VS, Bolshette NB, Gogoi R, Lahkar M (2014) Pharmacogenomics Study of Clopidogrel by RFLP based Genotyping of CYP2C19 in Cardiovascular Disease Patients in North-East Population of India. J Pharmacogenomics Pharmacoproteomics 5: 132. doi:10.4172/2153-0645.1000132

Page 3 of 5

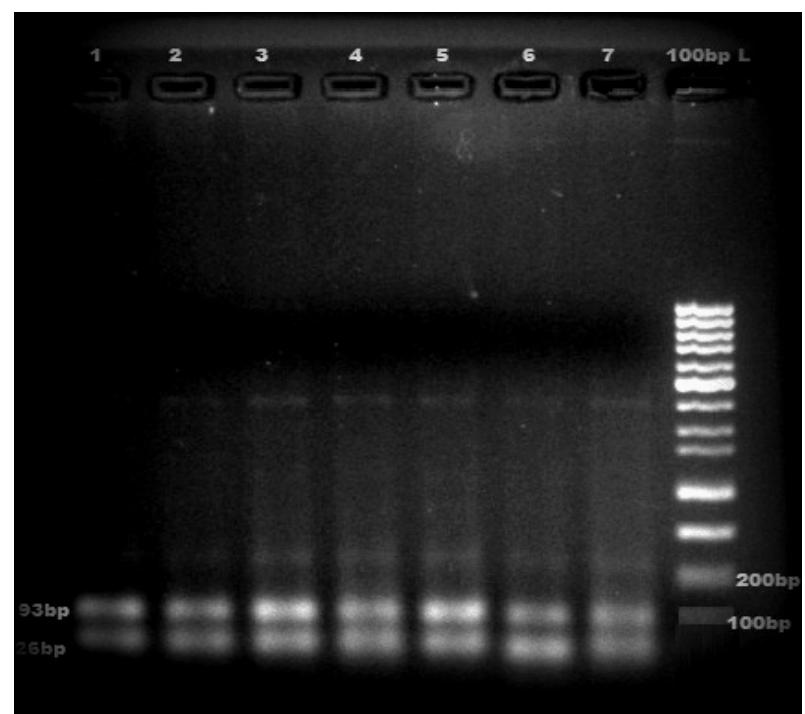

Lane 1, 2, 3, 4, 5, 6, 7: are wild type; lane 8: 100bp molecular weight marker Figure 2: PCR-RFLP based genotyping of CYP2C19 gene allele *3.

\begin{tabular}{|c|c|c|c|}
\hline $\begin{array}{c}\text { Allele } \\
\text { Designation }\end{array}$ & $\begin{array}{c}\text { Nucleotide } \\
\text { Change }\end{array}$ & Mutation Effect & $\begin{array}{c}\text { Predicted Enzyme } \\
\text { Activity }\end{array}$ \\
\hline${ }^{*} 2$ & c.681 G>A & Splicing defect & Non-functional \\
\hline$* 3$ & c.636 G>A & New stop codon & Non-functional \\
\hline$* 17$ & c. $991 \mathrm{~A}>\mathrm{G}$ & Increased gene transcription & Increased function \\
\hline
\end{tabular}

Note: The genotype reported as "no allelic variants" is suggestive of * 1 alleles.

Table 2: Allelic variants tested for CYP2C19 gene.

\begin{tabular}{|c|c|c|c|c|}
\hline Polymorphism & GG & GA & AA & Total \\
\hline rs4244285 & 36 & 24 & 0 & 60 \\
\hline rs4986893 & 60 & 0 & 0 & 60 \\
\hline \multicolumn{5}{|c|}{ Genotype Frequency } \\
\hline CYP2C19*2 & 60 & 40 & 0 & 100 \\
\hline CYP2C19*3 & 100 & 0 & 0 & 100 \\
\hline
\end{tabular}

Table 3: Polymorphisms observed in CYP2C19 gene with *2, *3 alleles and their Genotype frequencies.

\begin{tabular}{|l|c|c|c|}
\hline Polymorphism & Total No. Of Individuals & G & A \\
\hline CYP2C19*2; rs4244285 & 60 & 0.6 & 0.4 \\
\hline CYP2C19*3; rs4986893 & 60 & 1 & 0 \\
\hline Polymorhism & Total No. Of Individuals & C & T \\
\hline CYP2C19*17; rs12248560 & 60 & 1 & 0 \\
\hline
\end{tabular}

Table 4: Allelic frequencies of CYP2C19*2, *3 and *17 alleles.

CYP2C19*3 and CYP2C19*17) and $p$ is the number of wild-type alleles at the corresponding CYP2C19*2, CYP2C19*3 and $C Y P 2 C 19^{\star} 17$ loci (Table 4).

\section{Statistical analysis}

Genotype and allele frequencies were calculated from the counts. Expected genotype numbers were calculated using the HardyWeinberg equation $\left(p^{2}+2 p q+q^{2}=1\right)$ using the allele numbers, where $q$ is the number of the variant alleles $\left(C Y P 2 C 19^{\star} 2, C Y P 2 C 19^{*} 3\right.$ and $\left.C Y P 2 C 19^{*} 17\right)$ and $p$ is the number of wild-type alleles at the corresponding $\mathrm{CYP} 2 \mathrm{C} 19^{\star} 2, \mathrm{CYP} 2 \mathrm{C} 19^{*} 3$ and $\mathrm{CYP} 2 \mathrm{C} 19^{\star} 17$ loci. The $\chi^{2}$ test $P$ value $(P>0.05)$ was consistent with the Hardy-Weinberg equilibrium (HWE). Data were recorded on a predesigned proforma

\begin{tabular}{|l|c|}
\hline Age yrs. $($ mean $\pm \mathrm{SD})$ & $50.66 \pm 10.10$ \\
\hline Gender $(\mathrm{M} \%)$ & $90 \%$ \\
\hline Platelet count $\left(10^{\wedge} 3 / \mu \mathrm{L}\right)$ & $150.06 \pm 40.06$ \\
\hline Haemoglobin $(\mathrm{g} / \mathrm{dl})$ & $11.74 \pm 2.06$ \\
\hline WBC $\left(10^{\wedge} 3 / \mu \mathrm{L}\right)$ & $10.402 \pm 5.46$ \\
\hline Neutrophils $\left(10^{\wedge} 3 / \mu \mathrm{l}\right)$ & $72.91 \% \pm 0.11$ \\
\hline Monophils $\left(10^{\wedge} 3 / \mu \mathrm{L}\right)$ & $90.18 \% \pm 2.86$ \\
\hline Eosinophils $\left(10^{\wedge} 3 / \mu \mathrm{L}\right)$ & $44.77 \% \pm 1.43$ \\
\hline Daignosis $\mathrm{At}$ Entry & \\
\hline Unstable Angina & $6.6 \%$ \\
\hline Myocardial Infarction & $23.33 \%$ \\
\hline Medical History & \\
\hline ACS & $23.33 \%$ \\
\hline CKD & $6.66 \%$ \\
\hline Stroke & $13.33 \%$ \\
\hline CAD & $26.66 \%$ \\
\hline Hypertension & $23.33 \%$ \\
\hline Smoker & $10 \%$ \\
\hline NSTEMI & $30 \%$ \\
\hline PTCA & $6.66 \%$ \\
\hline & \\
\hline
\end{tabular}

Table 5: Baseline Demographics and Past Medical History.

and managed on an MS Office Excel Spread sheet. The descriptive statistics were represented by mean \pm standard deviation and percentage (Table 5).

\section{Discussion}

This study aimed to determine the influence of genetic variations related to the cardiovascular disease patients who were on clopidogrel treatment at the time of the event. Clopidogrel is a thienopyridine prodrug that requires hepatic biotransformation to form an active metabolite that selectively and irreversibly inhibits the purinergic $\mathrm{P} 2 \mathrm{RY}_{12}$ receptor, and thereby platelet aggregation, for the platelet's life span ( 10 days) [37-39]. Only $15 \%$ of the prodrug is available for transformation to the active agent; other $85 \%$ is hydrolyzed by esterases to inactive forms. Conversion of clopidogrel to its active metabolite requires two sequential oxidative steps involving several CYP450 enzymes (e.g., CYP1A2, CYP2B6, CYP2C9, CYP2C19, and CYP3A4/5) [40].The hepatic CYP2C19 enzyme contributes to the metabolism of many clinically relevant drugs such as antidepressants, benzodiazepines, mephenytoin, some proton pump inhibitors, and clopidogrel. Like many other CYP450 super-family members, the CYP2C19 gene is highly polymorphic, having more than 25 known variant alleles (http://www.cypalleles.ki.se/cyp2c19.htm). The CYP2C19*1 allele is associated with functional CYP2C19-mediated metabolism. The most common CYP2C19 loss-of-function allele is ${ }^{\star} 2$ (c.681G $>\mathrm{A}$; rs4244285), with allele frequencies of $\sim 15 \%$ in Caucasians and Africans, and 29$35 \%$ in Asians $[38,39,41,42]$.

We found that CYP2C19 2 had allelic frequency of $\sim 40 \%$ in Gauhati Medical College and Hospital, Assam, North East India. None of the samples were mutated with $C Y P 2 C 19^{*} 3$ and $C Y P 2 C 19^{*} 17$ allele. Other CYP2C19variant alleles with reduced or absent enzymatic activity have been identified (e.g., ${ }^{\star} 3-{ }^{\star} 8$ ); however, their allele frequencies are typically $<1 \%$, with the exception of CYP2C19*3 (c.636G $>A$; rs4986893) in Asians (2-9\%) (Table 4). CYP2C19 2 is inherited as an autosomal codominant trait; platelet responsiveness to clopidogrel in heterozygotes $\left({ }^{\star} 1{ }^{*} 2\right)$ lies somewhere between the responsiveness in individuals with the ${ }^{\star} 1 /{ }^{*} 1$ genotype and that in those with the ${ }^{\star} 2 /{ }^{*} 2$ genotype 
Citation: Prasanthi SV, Jamdade VS, Bolshette NB, Gogoi R, Lahkar M (2014) Pharmacogenomics Study of Clopidogrel by RFLP based Genotyping of CYP2C19 in Cardiovascular Disease Patients in North-East Population of India. J Pharmacogenomics Pharmacoproteomics 5: 132. doi:10.4172/2153-0645.1000132

Page 4 of 5

[24,27-29,31,32]. Therefore, based on identified CYP2C19 genotypes, individuals can be categorized as extensive metabolizers (e.g., ${ }^{\star} 1 /{ }^{\star} 1$ ), intermediate metabolizers (e.g., $\left.{ }^{\star} 1 /{ }^{\star} 2\right)$, or poor metabolizers (e.g., ${ }^{\star} 2 /{ }^{\star} 2$ ). In contrast, the CYP $2 C 19^{\star} 17$ allele (c. $-806 \mathrm{C}>\mathrm{T}$; rs 12248560$)$ results in increased activity as a consequence of enhanced transcription, with average multi-ethnic allele frequencies of $\sim 3-21 \%[33,34]$. Individuals who carry this allele may be categorized as ultra-rapid metabolizers (e.g., ${ }^{*} 17 /{ }^{*} 17$ ). Some studies indicate that this allele results in enhanced platelet inhibition and clopidogrel response, and possibly an increased risk of bleeding complications [28]. However, other studies have not identified an effect of $C Y P 2 C 19^{\star} 17[31,35,36]$, and adequate evidence for an independent effect of this allele on clinical outcomes is lacking.Probably this was the first study carried out in North East Indian population which had a higher prevalence rate of CYP2C19*2 40\% when compared with allele frequencies of $\sim 15 \%$ in Caucasians and Africans, and $29-35 \%$ in Asians. This study will help to make best use of benefit path and reducing harm how appears to lie in stratifying patient individuality in response to the treatment. This genetic testing aims to match treatment to an individual genetic profile. It will be helpful in designing clinical trials particularly at initial phases of drug development.It helps to reduce the number of patients needed, prove efficiency, and identify subgroups in trial design, also alternative treatment can be targeted. Over recent years, genetic testing has been increasingly used in clinical practice. Newer antiplatelet agents are failed to demonstrate superiority to clopidogrel without trade off of more bleeding [42-47]. The functional information on variants is important for justifying its clinical use. Understanding the functional meanings of CYP2C19 variants is an essential step toward shifting the current medical paradigm to highly personalised therapeutic regimen. The clinical decision strategies following CYP2C19 genotyping suggest two regimens: 1) an adjustment of drug dose according to genotype 2) an alternative drug choice [48].

To date the pharmacogenomic data on CYP2C19 clearly supports the genetic variants alter the drug response of its substrate drugs. However, clinical application of CYP2C19 pharmacogenetics is limited to certain genotypes [49]. The number of study population that would benefit from pharmacogenomics research would be greatly reduced if such studies focused on common variants for strong statistically evidence. One goal of pharmacogenomics is to provide personalised medicine and to provide an appropriate dose of the most appropriate drug to him or her. Therefore, more diversified investigations.

\section{Conclusion}

In conclusion, we have shown that loss of functional allele CYP2C19*2 had higher carriage frequency; whereas, CYP2C19*3 and ${ }^{*} 17$ alleles were not found in cardiovascular patients who were taking clopidogrel, in Gauhati Medical College and Hospital, Assam, North East India. Personalized therapy to target patient's carrying these genetic variants might help to improve the clinical outcome.Our findings suggest that CYP2C19 loss of functional allele had higher carriage frequency in northeast Indian population, furthermore studies on large sample size are needed in this population so that before prescribing the medication through the detection of these alleles in a patient may help reduce the harmful adverse events and so that necessary steps should be taken like changing the dose or prescribing alternative drugs. More comprehensive and diverse research wrapping a large number of CYP2C19 variants will lay the foundation for better adapted medicine for future.

\section{Acknowledgement}

The first author expresses his sincere thanks to National Institute of Pharmaceutical Education and Research (NIPER), Guwahati for providing financia assistance to carry out this work. Funding source had no involvement in study design; in the collection, analysis and interpretation of data; in the writing of the report; and in the decision to submit the article for publication.

\section{Conflict of Interest}

The authors declare that they have no competing interests or conflict of interests.

\section{References}

1. Brockmöller J, Tzvetkov MV (2008) Pharmacogenetics: data, concepts and tools to improve drug discovery and drug treatment. Eur J Clin Pharmacol 64: 133-157.

2. Marsh S, McLeod HL (2006) Pharmacogenomics: from bedside to clinical practice. Hum Mol Genet 15 Spec No 1: R89-93.

3. Goldstein DB, Tate SK, Sisodiya SM (2003) Pharmacogenetics goes genomic Nat Rev Genet 4: 937-947.

4. Wolf CR, Smith G (1999) Pharmacogenetics. Br Med Bull 55: 366-386.

5. Wolf CR, Smith G, Smith RL (2000) Science, medicine, and the future Pharmacogenetics. BMJ 320: 987-990.

6. Evans WE, Relling MV (1999) Pharmacogenomics: translating functional genomics into rational therapeutics. Science 286: 487-491.

7. Mehta SR, Yusuf S, Peters RJ, Bertrand ME, Lewis BS, et al. (2001) Effects of pretreatment with clopidogrel and aspirin followed by long-term therapy in patients undergoing percutaneous coronary intervention: the PCI-CURE study. Lancet 358: 527-533.

8. Cutlip DE, Baim DS, Ho KK, Popma JJ, Lansky AJ, et al. (2001) Stent thrombosis in the modern era: a pooled analysis of multicenter coronary stent clinical trials. Circulation 103: 1967-1971.

9. lakovou I, Schmidt T, Bonizzoni E, Ge L, Sangiorgi GM, et al. (2005) Incidence, predictors, and outcome of thrombosis after successful implantation of drugeluting stents. JAMA 293: 2126-2130.

10. Daemen J, Wenaweser P, Tsuchida K, Abrecht L, Vaina S, et al. (2007) Early and late coronary stent thrombosis of sirolimus-eluting and paclitaxel-eluting stents in routine clinical practice: data from a large two-institutional cohort study. Lancet 369: 667-678.

11. Kuchulakanti PK, Chu WW, Torguson R, Ohlmann P, Rha SW, et al. (2006) Correlates and long-term outcomes of angiographically proven stent thrombosis with sirolimus- and paclitaxel-eluting stents. Circulation 113: 1108-1113.

12. Smit JJ, van 't Hof AW, de Boer MJ, Hoorntje JC, Dambrink JH, et al. (2006) Incidence and predictors of subacute thrombosis in patients undergoing primary angioplasty for an acute myocardial infarction. Thromb Haemost 96: 190-195.

13. van Werkum JW, Heestermans AA, Zomer AC, Kelder JC, Suttorp MJ, et al (2009) Predictors of coronary stent thrombosis: the Dutch Stent Thrombosis Registry. J Am Coll Cardiol 53: 1399-1409.

14. Buonamici P, Marcucci R, Migliorini A, Gensini GF, Santini A, et al. (2007) Impact of platelet reactivity after clopidogrel administration on drug-eluting stent thrombosis. J Am Coll Cardiol 49: 2312-2317.

15. Sibbing D, Braun S, Morath T, Mehilli J, Vogt W, et al. (2009) Platelet reactivity after clopidogrel treatment assessed with point-of-care analysis and early drugeluting stent thrombosis. J Am Coll Cardiol 53: 849-856.

16. Angiolillo DJ, Fernandez-Ortiz A, Bernardo E, Alfonso F, Macaya C, et al. (2007) Variability in individual responsiveness to clopidogrel: clinical implications, management, and future perspectives. J Am Coll Cardiol 49: 1505-1516.

17. Kuliczkowski W, Witkowski A, Polonski L, Watala C, Filipiak K, et al. (2009) Interindividual variability in the response to oral antiplatelet drugs: a position paper of the Working Group on antiplatelet drugs resistance appointed by the Section of Cardiovascular Interventions of the Polish Cardiac Society, endorsed by the Working Group on Thrombosis of the European Society of Cardiology. Eur Heart J 30: 426-435.

18. Pereillo JM, Maftouh M, Andrieu A, Uzabiaga MF, Fedeli O, et al. (2002) Structure and stereochemistry of the active metabolite of clopidogrel. Drug Metab Dispos 30: 1288-1295 
Citation: Prasanthi SV, Jamdade VS, Bolshette NB, Gogoi R, Lahkar M (2014) Pharmacogenomics Study of Clopidogrel by RFLP based Genotyping of CYP2C19 in Cardiovascular Disease Patients in North-East Population of India. J Pharmacogenomics Pharmacoproteomics 5: 132. doi:10.4172/2153-0645.1000132

19. Savi P, Pereillo JM, Uzabiaga MF, Combalbert J, Picard C, et al. (2000) Identification and biological activity of the active metabolite of clopidogrel. Thromb Haemost 84: 891-896.

20. Angiolillo DJ, Fernandez-Ortiz A, Bernardo E, Ramírez C, Cavallari U, et al. (2006) Contribution of gene sequence variations of the hepatic cytochrome P450 3A4 enzyme to variability in individual responsiveness to clopidogrel. Arterioscler Thromb Vasc Biol 26: 1895-1900.

21. Giusti B, Gori AM, Marcucci R, Saracini C, Sestini I, et al. (2007) Cytochrome P450 2C19 loss-of-function polymorphism, but not CYP3A4 IVS10 + 12G/A and $\mathrm{P} 2 \mathrm{Y} 12 \mathrm{~T} 744 \mathrm{C}$ polymorphisms, is associated with response variability to dual antiplatelet treatment in high-risk vascular patients. Pharmacogenet Genomics 17: 1057-1064.

22. Harmsze A, van Werkum JW, Bouman HJ, Ruven HJ, Breet NJ, et al. (2010) Besides CYP2C $19^{*} 2$, the variant allele CYP2C $* 3$ is associated with higher onclopidogrel platelet reactivity in patients on dual antiplatelet therapy undergoing elective coronary stent implantation. Pharmacogenet Genomics 20: 18-25.

23. Hetherington SL, Singh RK, Lodwick D, Thompson JR, Goodall AH, et al. (2005) Dimorphism in the P2Y1 ADP receptor gene is associated with increased platelet activation response to ADP. Arterioscler Thromb Vasc Biol 25: 252-257.

24. Hulot JS, Bura A, Villard E, Azizi M, Remones V, et al. (2006) Cytochrome P450 2C19 loss-of-function polymorphism is a major determinant of clopidogre responsiveness in healthy subjects. Blood 108: 2244-2247.

25. Suh JW, Koo BK, Zhang SY, Park KW, Cho JY, et al. (2006) Increased risk of atherothrombotic events associated with cytochrome P450 3A5 polymorphism in patients taking clopidogrel. CMAJ 174: 1715-1722.

26. Trenk D, Hochholzer W, Fromm MF, Chialda LE, Pahl A, et al. (2008) Cytochrome P450 2C19 681G>A polymorphism and high on-clopidogrel platelet reactivity associated with adverse 1-year clinical outcome of elective percutaneous coronary intervention with drug-eluting or bare-metal stents. J Am Coll Cardiol 51: 1925-1934.

27. Brandt JT, Close SL, Iturria SJ, Payne CD, Farid NA, et al. (2007) Common polymorphisms of CYP2C19 and CYP2C9 affect the pharmacokinetic and pharmacodynamic response to clopidogrel but not prasugrel. J Thromb Haemost 5: 2429-2436.

28. Collet JP, Hulot JS, Pena A, Villard E, Esteve JB, et al. (2009) Cytochrome P450 2C19 polymorphism in young patients treated with clopidogrel after myocardial infarction: a cohort study. Lancet 373: 309-317.

29. Mega JL, Close SL, Wiviott SD, Shen L, Hockett RD, et al. (2009) Cytochrome p-450 polymorphisms and response to clopidogrel. N Engl J Med 360: 354-362.

30. Mega JL, Close SL, Wiviott SD, Shen L, Hockett RD, et al. (2009) Cytochrome P450 genetic polymorphisms and the response to prasugrel: relationship to pharmacokinetic, pharmacodynamic, and clinical outcomes. Circulation 119: 2553-2560.

31. Shuldiner AR, O'Connell JR, Bliden KP, Gandhi A, Ryan K, et al. (2009) Association of cytochrome P450 2C19 genotype with the antiplatelet effect and clinical efficacy of clopidogrel therapy. JAMA 302: 849-857.

32. Umemura K, Furuta T, Kondo K (2008) The common gene variants of CYP2C19 affect pharmacokinetics and pharmacodynamics in an active metabolite of clopidogrel in healthy subjects. J Thromb Haemost 6: 1439-1441.

33. Frére C, Cuisset T, Gaborit B, Alessi MC, Hulot JS (2009) The CYP2C19*17 allele is associated with better platelet response to clopidogrel in patients admitted for non-ST acute coronary syndrome. J Thromb Haemost 7: 14091411.

34. Tiroch KA, Sibbing D, Koch W, Roosen-Runge T, Mehilli J, et al. (2010) Protective effect of the CYP2C19 *17 polymorphism with increased activation of clopidogrel on cardiovascular events. Am Heart J 160: 506-512.

35. Geisler T, Schaeffeler E, Dippon J, Winter S, Buse V, et al. (2008) CYP2C19 and nongenetic factors predict poor responsiveness to clopidogrel loading dose after coronary stent implantation. Pharmacogenomics 9: 1251-1259.
36. Simon T, Verstuyft C, Mary-Krause M, Quteineh L, Drouet E, et al. (2009) Genetic determinants of response to clopidogrel and cardiovascular events. N Engl J Med 360: 363-375.

37. Kim KA, Park PW, Hong SJ, Park JY (2008) The effect of CYP2C19 polymorphism on the pharmacokinetics and pharmacodynamics of clopidogrel: a possible mechanism for clopidogrel resistance. Clin Pharmacol Ther 84: 236 242.

38. Giusti B, Gori AM, Marcucci R, Saracini C, Sestini I, et al. (2009) Relation of cytochrome P450 2C19 loss-of-function polymorphism to occurrence of drugeluting coronary stent thrombosis. Am J Cardiol 103: 806-811.

39. Sibbing D, Stegherr J, Latz W, Koch W, Mehilli J, et al. (2009) Cytochrome P450 2C19 loss-of-function polymorphism and stent thrombosis following percutaneous coronary intervention. Eur Heart J 30: 916-922.

40. Bouman HJ, Schömig E, van Werkum JW, Velder J, Hackeng CM, et al. (2011) Paraoxonase-1 is a major determinant of clopidogrel efficacy. Nat Med 17: 110116.

41. Mega JL, Simon T, Collet JP, Anderson JL, Antman EM, et al. (2010) Reducedfunction CYP2C19 genotype and risk of adverse clinical outcomes among patients treated with clopidogrel predominantly for $\mathrm{PCl}$ : a meta-analysis. JAMA 304: $1821-1830$

42. Sibbing D, Gebhard D, Koch W, Braun S, Stegherr J, et al. (2010) Isolated and interactive impact of common CYP2C19 genetic variants on the antiplatelet effect of chronic clopidogrel therapy. J Thromb Haemost 8: 1685-1693.

43. Freedman JE, Hylek EM (2009) Clopidogrel, genetics, and drug responsiveness. N Engl J Med 360: 411-413.

44. Mega JL, Close SL, Wiviott SD, Shen L, Hockett RD, et al. (2009) Cytochrome P450 genetic polymorphisms and the response to prasugrel: relationship to pharmacokinetic, pharmacodynamic, and clinical outcomes. Circulation 119 2553-2560.

45. Mega JL, Close SL, Wiviott SD, Shen L, Walker JR, et al. (2010) Genetic variants in $\mathrm{ABCB} 1$ and $\mathrm{CYP} 2 \mathrm{C} 19$ and cardiovascular outcomes after treatment with clopidogrel and prasugrel in the TRITON-TIMI 38 trial: a pharmacogenetic analysis. Lancet 376: 1312-1319.

46. Trenk D, Hochholzer W, Fromm MF, Chialda LE, Pahl A, et al. (2008) Cytochrome P450 2C19 681G>A polymorphism and high on-clopidogrel platelet reactivity associated with adverse 1-year clinical outcome of elective percutaneous coronary intervention with drug-eluting or bare-metal stents. J Am Coll Cardiol 51: 1925-1934.

47. Wallentin L, James S, Storey RF, Armstrong M, Barratt BJ, et al. (2010) Effect of CYP2C19 and ABCB1 single nucleotide polymorphisms on outcomes of treatment with ticagrelor versus clopidogrel for acute coronary syndromes: a genetic substudy of the PLATO trial. Lancet 376: 1320-1328.

48. Lee SJ (2013) Clinical Application of CYP2C19 Pharmacogenetics Toward More Personalized Medicine. Front Genet 3: 318.

49. Michaud V, Kreutz Y, Skaar T, Ogburn E, Thong N, et al. (2014) Efavirenzmediated induction of omeprazole metabolism is CYP2C19 genotype dependent. Pharmacogenomics J 14: 151-159. 